\title{
Editorial
}

\section{Geomorphology and Climate - In honour of Professor Dr Eduard A. Koster}

\author{
H. Middelkoop ${ }^{*}$, E. Stouthamer \& W.Z. Hoek
}

Department of Physical Geography, Utrecht University, P.0. Box 80115, 3508 TC Utrecht, the Netherlands.

* Corresponding author. Email: h.middelkoop@geo.uu.nl

This special issue of the Netherlands Journal of Geosciences is dedicated to Professor Dr Eduard A. Koster at the occasion of his retirement from the Department of Physical Geography, Utrecht University in November 2005. With this issue we want to honour his scientific achievements, his contribution to the education of thousands of students in geography, geology and biology, his work at our Department and in numerous scientific organisations, and his contributions to the scientific careers of his co-workers and PhD students. Over the past 37 years Ward Koster has become a leading scientist in the fields of aeolian and periglacial geomorphology, Quaternary geology and climate change.

Ward studied physical geography and Quaternary geology at the Laboratory of Physical Geography and Soil Science of the University of Amsterdam. In 1965 he received his Candidate (BSc) degree in physical geography, and in 1968 his 'Doctoraal' (MSc) degree in physical geography and geomorphology. As a student he visited the McGill University, Geography Department, Montreal, Canada and McGill Subarctic Research Station, Schefferville for a 6-months period. In October 1978 he received his PhD from the University of Amsterdam for his thesis entitled: 'The eolian drift sands of the Veluwe (central Netherlands): a physical geographical study' (promotor: Prof. Dr Maarleveld) (Koster, 1978). From 1969 to 1980 Ward was employed as scientific researcher at the Laboratory of Physical Geography and Soil Science, where he became Professor in 1980. Between 1983 and 1985 he was Dean of the Subfaculty Physical Geography of the University of Amsterdam. During his 'Amsterdam-period' Ward became engaged in research on geomorphologic mapping, aeolian landscapes and periglacial environments, contributing field visits to numerous countries with Iceland, Canada, Alaska and Greenland as his favourites.

In December 1985 Ward was appointed Professor in Physical Geography and Geomorphology at the Geographical Institute of Utrecht University. Under his supervision and with Dr Henk Berendsen* as associate-professor the geomorphology group

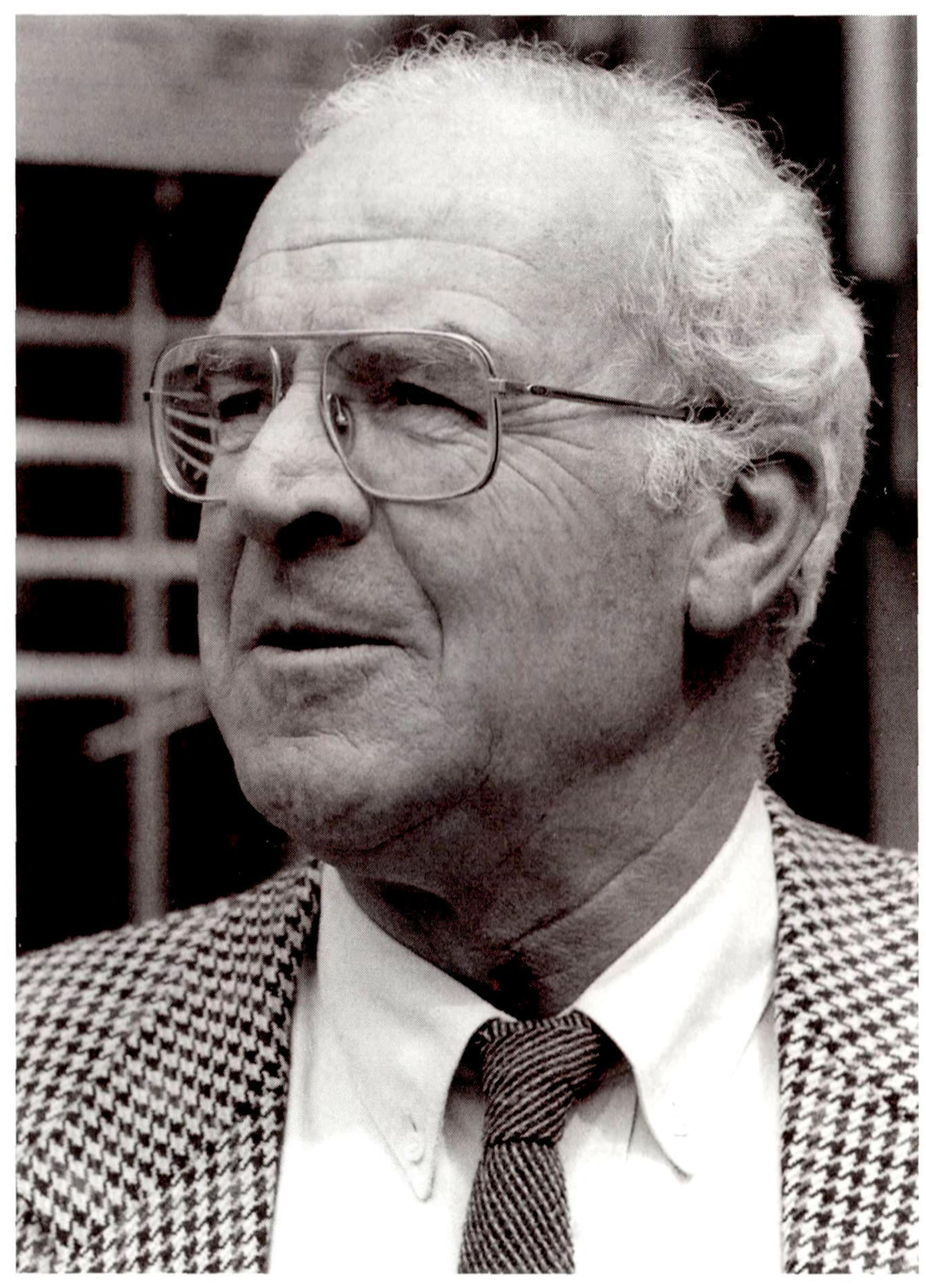

Professor Dr E.A. Koster

in Utrecht entered a new era of research. Firstly, the RhineMeuse delta evolution project gained considerable impetus by the acquisition of new PhD projects (table 1). These involved the $3 \mathrm{D}$ evolution of the delta during the Holocene, changing river patterns and avulsions, the impact of sea level change and tectonics on the delta, OSL dating of fluvial sediments, and sediment budgets of the Rhine. River studies that considered shorter time scales involved sediment sorting, 
channel bed dune formation and downstream fining in sand and gravel bed rivers. These projects were undertaken in close cooperation with the Dutch Institute for Inland Water Management and Wastewater Treatment (RIZA). With studies on geomorphological change and river rehabilitation, floodplain development in historic time, and on hydraulic roughness of floodplain vegetation, Ward achieved that his research group was able to establish a bridge between scientific research and application in river management.

In addition to river studies, Ward initiated a novel research programme at the Department focusing on climate reconstruction and climate impact assessment. As a continuation of his work in cold-climate regions, research was undertaken in Greenland on proglacial lakes, of which the sediments contained unique climate records. In a joint project with the Vrije Universiteit Amsterdam (Prof. Dr Vandenberghe) geomorphological indicators were successfully combined with modelling experiments using a GCM to reconstruct the climate in NWEurope during the Younger Dryas. In a joint project with the Byrd Polar Research Center of the Ohio State University, LateQuaternary climate change and vegetation patterns in the subarctic Beringia region were investigated. Then, by initialising climate impact studies, Ward established a new research track, anticipating to the research needs associated with future global warming. The first project on the impacts of climate change on the discharge of the Rhine River was extremely well timed, as the thesis of Jaap Kwadijk appeared just days before the large flood of the Rhine by the end of 1993. Likewise, the subsequent studies on the implications for sediment transport and floodplain development could not be scheduled better in view of the large floods in 1993 and 1995, and the increasing interest in floodplain management. The $\mathrm{PhD}$ projects on climate sensitivity of European rivers, and on the impacts of climate change on subarctic rivers in Northern Russia and Scandinavia further contributed to our understanding of river responses to global change. Several of these studies were carried out within the framework of the Dutch National Research Programmes on Climate Change (NRP) and EU projects, and were conducted in close cooperation with international institutes on climate research and water management. With these projects the Physical Geography Department became a serious international player in the field of climate research and climate impact studies.

The success of the research conducted under Ward's guidance was very much the result of Ward's excellent feeling for 'trends and needs' in research on geomorphology and climate. In terms of the S-curve of progress against effort, the studies carried out at our department could be found on the steep rising part of the curve. In his delta evolution project Henk Berendsen already had gone through the lower limb representing the initiation stage, and after Ward's advent, the project proceeded in the rising limb of progress: the sequence of PhD projects all having the benefits of the long preparatory work of Henk Berendsen. Likewise, Ward started the climate impact studies right at the time there was a great need for such studies, both scientifically, and for water management in the Netherlands and Europe.

Another aspect of Ward's work that cannot be underestimated is his contribution to numerous national and international scientific boards and committees, amongst which we can mention the Dutch Council for Scientific Research (NW0), Royal Dutch Academy of Sciences (KNAW), Netherlands Centre for River Research (NCR), International Union for Quaternary Research (INQUA), International Geographical Union (IGU), International Permafrost Association (IPA). With Prof. Dr Pissart from the University of Liège, Belgium and Prof. Dr French from the University of Ottawa, Canada he formed the editorial board from the first hour of the international journal 'Permafrost and Periglacial Processes'. Due to these activities he had a broad overview on the scientific arena, and he made significant contributions to the research agenda for climate change and climate impact assessment in the Netherlands.

Ward has been able to build-up a research group of young and enthusiastic people, each with his or her own expertise, who were able to share their skills amongst each other, and who worked together as a team. This not only has led to a successful completion of about $30 \mathrm{PhD}$ theses, but for most of us the PhD work under Ward formed a great starting point of a scientific career in the fields of geomorphology, climate research, impact assessment and water management.

On the 30th of November 2005 Ward Koster retired from his position as professor of Physical Geography and Geomorphology at Utrecht University. To mark this event and to honour the achievements of his work during his 20 years at our Department, a symposium was held on this day. In the morning session, presentations were given by a selection of his former $\mathrm{PhD}$ students on periglacial aeolian morphology, climate and water management, river deltas at risk, climate modelling, climate records in arctic lakes on Greenland, and luminescence dating of sand. In the afternoon, presentations were given by Prof. Dr French on the changing nature of periglacial geomorphology, and Prof. Dr Pissart on global change and permafrost. The day was concluded by the farewell lecture by Prof. Dr Koster entitled: 'De aarde leeft langzaam, maar de natuur is nukkig. Beschouwingen over morfodynamiek en klimaatverandering', in which he gave an interesting overview on climate variability, global change, and climate impacts on rivers and periglacial environments.

As a follow-up of the symposium this special issue is devoted to the work of Ward in the past 20 years. It contains a selection of papers written by colleagues and former PhD students from the Department of Physical Geography. With this issue we do not attempt to provide a complete overview of the work of Ward or the fields of work of all his former PhD students. Still, it shows examples of the wide and fascinating 
research in geomorphology, rivers and climate that have been carried out at our department. We have arranged the papers more or less in order of decreasing time scale of the considered themes. In the first paper Berendsen* (2007) describes the history of geological mapping of the Holocene Rhine-Meuse delta in the Netherlands, from the first geological mapping in the early 20th century until the extremely detailed coring database and digital maps available now at the Department of Physical Geography. The paper of Wallinga et al. (2007) demonstrates the application of 0ptically Stimulated Luminescence dating to various types of sediment in the Netherlands. Schokker et al. (2007) argue in their paper that application of the traditional lithostratigraphic framework to subdivide the Middle- and Upper-Quaternary locally-derived deposits in the Netherlands is problematic. They present a new lithostratigraphy for these fine-grained deposits, based on detailed research in the central part of the Roer Valley Graben. Gouw (2007) provides an overview of the current state of research on alluvial architecture with special reference to Holocene fluvio-deltaic settings. He shows architectural elements in fluvial successions and demonstrates the influence of the various controls on alluvial architecture using examples from the Holocene Rhine-Meuse delta (the Netherlands) and the Lower Mississippi Valley (USA). Hebinck et al. (2007) report on first attempts to apply radiometric fingerprinting techniques to distinguish fine-grained floodbasin deposits originating from the Rhine or Meuse basins. The paper by Makaske et al. (2007) shows that Quaternary science in river deltas not only contributes to archaeologic research in the Rhine-Meuse delta, but that such integration of both specialisms can also be applied to floodplains in Central Africa. Wolfert \& Maas (2007) have reconstructed the meandering history of the Overijsselse Vecht River, a tributary of one of the lower Rhine branches in Eastern Netherlands. By analysing the meandering stages and their controls, they provide a geomorphologic underpinning for rehabilitation projects of small lowland rivers. The paper of Kleinhans et al. (2007) focuses on the morphological behaviour of the lower Rhine channel bed at the bifurcation point with the Pannerdens Canal. They discuss complex hysteresis phenomena in sediment transport against discharge, and the implications for sediment transport modelling. Van den Berg et al. (2007) investigated sedimentary records to distinguish in a sedimentary sense a separate transitional zone between the upstream fluvial and downstream estuarine environments. They propose a sedimentological definition of the fluvial-tidal zone with characteristic sedimentary signatures. Finally, Törnqvist (2007) places the Katrina disaster of New Orleans (2005) in a geomorphologic perspective. He provides a spectacular example of the more generic problem of sea level rise, soil subsidence and climate change for flood management in river deltas and coastal wetlands.
On behalf of his colleagues and former PhD students we once again want to express our gratitude to Ward for giving us the opportunity to carry out research in these challenging fields of geomorphology and climate change. We very much have appreciated his scientific and personal support, his open mindedness in letting us developing our own research path, while at the right time pulling us onto the right track, and discussing the key questions of the research. Finally, we thank the Netherlands Journal of Geosciences for facilitating the publication of the papers in this special issue, the authors for their interesting contributions and the many reviewers for their careful efforts.

\section{References}

Berendsen, H.J.A., 2007. History of geological mapping of the Holocene RhineMeuse delta, the Netherlands. Netherlands Journal of Geosciences 86/3: 165-177.

Gouw, M.J.P., 2007. Alluvial architecture of fluvio-deltaic successions: a review with special reference to Holocene settings. Netherlands Journal of Geosciences 86/3: 211-227.

Hebinck, K., Middelkoop, H., Van Diepen, N., Van der Graaf, E.R. \& De Meijer, R.J., 2007. Radiometric fingerprinting of fluvial sediments in the Rhine-Meuse delta, the Netherlands - a feasibility test. Netherlands Journal of Geosciences 86/3: 229-240.

Kleinhans, M.G., Wilbers, A.W.E. \& Ten Brinke, W.B.M., 2007. Opposite hysteresis of sand and gravel transport up- and downstream of a bifurcation during a flood in the River Rhine, the Netherlands. Netherlands Journal of Geosciences 86/3: 273-285.

Koster, E.A., 1978. De stuifzanden van de Veluwe: een fysisch geografische studie (Eolian drift sands of the Veluwe, Central Netherlands). Publicaties van het Fysisch Geografisch en Bodemkundig Laboratorium, Thesis Universiteit van Amsterdam, $195 \mathrm{pp}$.

Makaske A., De Vries, E., Tainter, J.A. \& McIntosh, R.J., 2007. Aeolian and fluviolacustrine landforms and prehistoric human occupation on a tectonically influenced floodplain margin, the Méma, central Mali. Netherlands Journal of Geosciences 86/3: 241-256.

Schokker, J., Weerts, H.J.T., Westerhoff, W.E., Berendsen H.J.A. \& Den Otter, C., 2007. Introduction of the Boxtel Formation and implications for the Quaternary lithostratigraphy of the Netherlands. Netherlands Journal of Geosciences 86/3: 197-210.

Törnqvist, T.E., 2007. A Dutch geoscience perspective on the Katrina disaster. Netherlands Journal of Geosciences 86/3: 307-315.

Van den Berg, J.H., Boersma, J.R. \& Van Gelder, A., 2007. Diagnostic sedimentary structures of the fluvial-tidal transition zone. Evidence from deposits of the Rhine and Meuse. Netherlands Journal of Geosciences 86-3: 287-306.

Wallinga, J., Davids, F. \& Dijkmans, J.W.A., 2007. Luminescence dating of Netherlands' sediments. Netherlands Journal of Geosciences 86/3: 179-196.

Wolfert, H.P. \& Maas, G.J., 2007. Downstream changes of meandering styles in the lower reaches of the River Vecht, the Netherlands. Netherlands Journal of Geosciences 86/3: 257-271.

* With great sadness we must commemorate that Henk Berendsen passed away on May 14th 2007, after a 3-year period of illness. 
Table 1. PhD theses completed and in preparation under supervision of Prof. Dr Eduard Koster.

\begin{tabular}{|c|c|c|}
\hline Name & Year & Title of PhD thesis \\
\hline Flor I. Van Zuidam-Cancelado & 1989 & $\begin{array}{l}\text { Desarrollo geomorfologico de la cuenca del Rio Aljucen y sus alrededores immediatos, } \\
\text { Extremadura, Espana }\end{array}$ \\
\hline Jos W.A. Dijkmans & 1990 & Aspects of geomorphology and thermoluminescence dating of cold-climate eolian sands \\
\hline Ilona I.Y. Castel & 1991 & Late Holocene eolian drift sands in Drenthe (the Netherlands) \\
\hline Torbjörn E. Törnqvist & 1993 & Fluvial sedimentary geology and chronology of the Holocene Rhine-Meuse delta, the Netherlands \\
\hline Jaap C.J. Kwadijk & 1993 & The impact of climate change on the discharge of the River Rhine \\
\hline Marc F.P. Bierkens & 1994 & Complex confining layers. A stochastic analysis of hydraulic properties at various scales \\
\hline Frank G.M. van Tatenhove & 1995 & $\begin{array}{l}\text { The dynamics of Holocene deglaciation in west Greenland with emphasis on recent ice-marginal } \\
\text { processes }\end{array}$ \\
\hline Henk J.T. Weerts & 1996 & $\begin{array}{l}\text { Complex confining layers. Architecture and hydraulic properties of Holocene and Late Weichselian } \\
\text { deposits in the fluvial Rhine-Meuse delta, the Netherlands }\end{array}$ \\
\hline Hans Renssen & 1997 & $\begin{array}{l}\text { The climate during the Younger Dryas stadial. Comparing global atmospheric simulation } \\
\text { experiments with climate reconstructions based on geological evidence }\end{array}$ \\
\hline Hans Middelkoop & 1997 & Embanked floodplains in the Netherlands. Geomorphological evolution over various time scales \\
\hline Birgitta van der Wateren - De Hoog & 1997 & Quantification of catchment discharge sensitivity to climate variability \\
\hline Nathalie E.M. Asselman & 1997 & $\begin{array}{l}\text { Suspended sediment in the River Rhine. The impact of climate change on erosion, transport, } \\
\text { and deposition }\end{array}$ \\
\hline Bart Makaske & 1998 & Anastomosing rivers. Forms, processes and sediments \\
\hline Wendy R. Eisner & 1999 & Climate change and spatial diversity of vegetation during the Late Quaternary of Beringia \\
\hline Nico W. Willemse & 2000 & Arctic natural archives. Lake and eolian sedimentary records from West Greenland \\
\hline Esther Stouthamer & 2001 & Holocene avulsions in the Rhine-Meuse delta, the Netherlands \\
\hline Henk P. Wolfert & 2001 & $\begin{array}{l}\text { Geomorphological change and river rehabilitation. Case studies on lowland fluvial systems in } \\
\text { the Netherlands }\end{array}$ \\
\hline Jakob Wallinga & 2001 & $\begin{array}{l}\text { The Rhine-Meuse system in a new light: optically stimulated luminescence dating and its } \\
\text { application to fluvial deposits }\end{array}$ \\
\hline Annika W. Hesselink & 2002 & $\begin{array}{l}\text { History makes a river. Morphological changes and human interference in the river Rhine, } \\
\text { the Netherlands }\end{array}$ \\
\hline Maarten G. Kleinhans & 2002 & Sorting out sand and gravel: sediment transport and deposition in sand-gravel bed rivers \\
\hline Rutger Dankers & 2002 & $\begin{array}{l}\text { Sub-arctic hydrology and climate change. A case study of the Tana River Basin in Northern } \\
\text { Fennoscandia }\end{array}$ \\
\hline Sandra van der Linden & 2002 & Icy rivers heating up. Modelling hydrological impacts of climate change in the (sub)arctic \\
\hline Jeroen Schokker & 2003 & $\begin{array}{l}\text { Patterns and processes in a Pleistocene fluvio-aeolian environment. Roer Valley Graben, } \\
\text { south-eastern Netherlands }\end{array}$ \\
\hline Kim M. Cohen & 2003 & $\begin{array}{l}\text { Differential subsidence within a coastal prism: Late-Glacial - Holocene tectonics in the } \\
\text { Rhine-Meuse delta, the Netherlands }\end{array}$ \\
\hline Antoine Wilbers & 2004 & The development and hydraulic roughness of subaqueous dunes \\
\hline Menno W. Straatsma & 2007 & Hydrodynamic roughness of floodplain vegetation \\
\hline Roy M. Frings & 2007 & Downstream fining of bed sediment in the Dutch Rhine branches \\
\hline Marc Gouw & 2007 & Quantification of alluvial architecture parameters of the Rhine-Meuse and Mississippi River deltas \\
\hline Gilles Erkens & 2008 & $\begin{array}{l}\text { The influence of climate, vegetation and human impact on the fluvial dynamics in the Rhine } \\
\text { drainage basin during the last } 15,000 \text { years }\end{array}$ \\
\hline Marc Hijma & 2009 & $\begin{array}{l}\text { From lowstand to highstand delta - development and architecture of the Late Pleistocene } \\
\text { and Holocene coastal area of the Rhine-Meuse delta in the Netherlands }\end{array}$ \\
\hline Ingwer J. Bos & 2010 & $\begin{array}{l}\text { Characterization of alluvial architecture and comparison of facies distribution of Holocene } \\
\text { and Early Pleistocene fine-grained fluvial deposits in the Netherlands }\end{array}$ \\
\hline Sanneke van Asselen & 2010 & The influence of peat compaction on river channel diversions and alluvial architecture \\
\hline
\end{tabular}

